\title{
EGG INCUBATION IN THE NOBLE CRAYFISH (ASTACUS ASTACUS L.): THE EFFECT OF CONTROLLED LABORATORY AND OUTDOOR AMBIENT CONDITION ON HATCHING SUCCESS, GROWTH AND SURVIVAL RATE OF JUVENILES
}

\author{
T. POLICAR (1), V. SIMON (2), P. KOZÁK (1)
}

(1) University of South Bohemia České Budějovice, Research Institute of Fish Culture and Hydrobiology in Vodňany, Zátiší 728/II, 38925 VODŇANY, Czech Republic. E-mail: policar@vurh.jcu.cz

(2) University of South Bohemia České Budějovice, Faculty of Agriculture, Studentská 13, 37005 ČESKÉ BUDĚJOVICE, Czech Republic.

Reçu le 06 janvier 2004

Accepté le 03 septembre 2004

Received January 06, 2004

Accepted September 03, 2004

\begin{abstract}
The incubation of eggs on pleopods of 13 female noble crayfish was controlled by means of water temperature after CUKERZIS et al. (1978). Out-door incubation of eggs on pleopods of 15 females was monitored at ambient temperature in an earthen storage pond. With controlled incubation of eggs, the duration of incubation period was shortened and earlier hatching resulted in so-called advanced juveniles. They hatched 88 days earlier than those normally hatched during out-door egg incubation. These 88 days prolonged the rearing period of advanced juvenile crayfish in the $1^{\text {st }}$ growing season. When the advanced juvenile crayfish were isolated, there resulted a significantly lower number of stage 2 juveniles per female kept under controlled conditions $(47 \pm 25.0$ individuals of stage 2 juveniles per female) compared to those females placed under out-door conditions (90.1 \pm 46.9 individuals of stage 2 juveniles per female). Two females lost all eggs during controlled egg incubation, while no females lost all eggs during out-door egg incubation.

After hatching, both groups (advanced and normally hatched juveniles) were provided with identical rearing conditions. Growth and survival rate were checked regularly. The advanced juvenile crayfish always reached significantly higher size in the given period than those normally hatched because they were 88 days older. At the end of rearing period (beginning of October), the advanced juveniles reached $26.0 \pm 3.06 \mathrm{~mm}$ mean body length and $0.585 \pm 0.197 \mathrm{~g}$ mean weight. In contrast, normally hatched juveniles reached $21.3 \pm 2.25 \mathrm{~mm}$ mean body length and $0.305 \pm 0.101 \mathrm{~g}$ mean weight. Comparing the growth of juveniles at a given age, the advance juveniles showed slower growth rate than those hatched normally. The advanced juveniles at 90 days of age $(20.2 \pm 1.83 \mathrm{~mm}$ mean body length, $0.207 \pm 0.058 \mathrm{~g}$ mean weight) had significantly slower growth than those hatched normally $(21.3 \pm 2.25 \mathrm{~mm}$ mean body length, $0.305 \pm 0.101 \mathrm{~g}$ mean weight). Apart from slower growth, the advanced juveniles also had a lower survival rate in the rearing period. In 90 days of age, the advanced juveniles showed $21 \%$ less survival rate than the normally hatched juveniles.
\end{abstract}

Key-words: Astacus astacus, noble crayfish, controlled and out-door egg incubation, rearing, growth, survival, juveniles. 


\section{INCUBATION DES CEUFS DE L'ÉCREVISSE À PATTES ROUGES (ASTACUS ASTACUS L.) : EFFETS DES CONDITIONS DE LABORATOIRE ET DES CONDITIONS EXTÉRIEURES AMBIANTES SUR LES TAUX D‘ÉCLOSION, DE CROISSANCE ET DE SURVIE DES JUVÉNILES}

\section{RÉSUMÉ}

L'incubation des œufs sous les pléopodes de 13 femelles d'écrevisse à pattes rouges a été contrôlée au moyen de la température de l'eau d'après CUKERZIS et al. (1978). L'incubation en milieu extérieur des œufs sous les pléopodes de 15 femelles a été suivie en condition thermique ambiante dans des étangs de stockage en terre. Avec une incubation contrôlée des œufs, la durée de la période d'incubation a été raccourcie et une éclosion précoce a permis la production de juvéniles précoces. Ils éclosent 88 jours plus tôt que ceux nés en conditions thermiques naturelles. Ces 88 jours allongent la période d'élevage des juvéniles précoces d'écrevisse pendant la première saison de grossissement. Quand ces juvéniles furent isolés, un nombre significativement plus faible de juvéniles au stade 2 a été observé sous des conditions contrôlées $(47,0 \pm 25,0$ individus par femelle) par comparaison avec les femelles maintenues en milieu extérieur $(90,1 \pm 46,9$ individus par femelle). Deux femelles perdirent tout leurs œufs pendant l'incubation contrôlée, alors qu'aucune femelle ne perdit tout ses œufs en condition extérieure.

Après l'éclosion, les deux groupes (juvéniles éclos précocement et normalement) furent maintenus dans des conditions d'élevage identiques. Les taux de survie et de croissance furent vérifiés régulièrement. Les juvéniles précoces ont toujours présenté une taille significativement supérieure par rapport aux juvéniles "normaux » car ils étaient âgés de 88 jours de plus. A la fin de la période d'élevage (début octobre), les juvéniles précoces atteignaient une longueur totale moyenne de 26,0 $\pm 3,06 \mathrm{~mm}$ et un poids moyen de 0,585 $\pm 0,197 \mathrm{~g}$. Par comparaison, les juvéniles éclos normalement présentaient une longueur totale moyenne de 21,3 $\pm 2,25 \mathrm{~mm}$ et un poids moyen de 0,305 $\pm 0,101 \mathrm{~g}$. En comparant la croissance des juvéniles à un âge donné, les juvéniles précoces montrent un taux de croissance plus faible par rapport à ceux éclos normalement. Les juvéniles précoces âgés de 90 jours $(20,2 \pm 1,83 \mathrm{~mm}$ de longueur totale, 0,207 $\pm 0,058 \mathrm{~g}$ de poids moyen) ont une croissance significativement plus faible que ceux éclos normalement $(21,3 \pm 2,25 \mathrm{~mm}, 0,305 \pm 0,101 \mathrm{~g})$. En plus d'une croissance plus faible, les juvéniles précoces ont aussi un plus faible taux de survie pendant la période d'élevage. A l'âge de 90 jours, les juvéniles précoces montrent un taux de survie inférieur de $21 \%$ par rapport à celui des juvéniles éclos normalement.

Mots-clés : Astacus astacus, écrevisse à pattes rouges, incubation des œufs, milieu contrôlé et extérieur, élevage, croissance, survie, juvéniles

\section{INTRODUCTION}

Various methods of production of stocking material in the noble crayfish are described (SKURDAL et al., 1989; ACKEFORS and LINDQVIST, 1994; TULONEN et al., 1995). All these methods are based upon incubation of eggs on pleopods of females under natural climatic conditions. Apart from this incubation of eggs, ACKEFORS (1993), CUKERZIS et al. (1978), CUKERZIS (1988, 1989), CELADA et al. (1988), CARRAL et al. (1992), KÖKSAL (1988), MACKEVIÈIENË et al. (1997), MASON (1977), PÉREZ et al. (1998, 1999), REYNOLDS et al. (1992) and RHODES (1981), describe the approach to controlled incubation of eggs by means of controlling the water temperature. The importance of temperature to the egg development of crayfish is well documented (WESTIN and GYDEMO, 1986; CUKERZIS, 1989; CELADA et al., 1988; CARRAL et al., 1992). There are methods of speeding up the embryonic development and achieving earlier hatching of the 
juveniles (ACKEFORS, 1993; CUKERZIS et al., 1978; CUKERZIS, 1989; HESSEN et al., 1987; MACKEVIÈIENË et al., 1997).

Juvenile crayfish with prolonged duration of rearing in the $1^{\text {st }}$ growing season gain at the end of this period higher values in terms of growth (body length and weight) and higher degree of development than juveniles hatched from normally incubated eggs (ACKEFORS, 1993). When restocked, the advanced crayfish survive better in the wild and also reach sexual maturity earlier (KOZÁK et al., 1998).

The period after hatching is the most critical one in a crayfish life, as the juveniles adapt to new life conditions (BLAKE and HART, 1993). It is important therefore to provide the juveniles after hatching and staying alone with optimal environmental conditions, eliminating losses as much as possible (REYNOLDS, 2002). NYSTRÖM (1994) reported the following 5 factors to be the most important for successful rearing of juvenile crayfish under artificial conditions: acceptable density of reared juveniles, sufficient number of shelters, light intensity at least 600 lux, enough fresh food and good quality of water. PURSIAINEN et al. (1983) proposed the stock density, reporting at the end of the $1^{\text {st }}$ growing season for noble crayfish juveniles' $58 \%$ and/or $50 \%$ survival, with the respective initial density 100 and/or 300 individuals in the stage 2 per square meter of rearing area. KELLER (1987a) reports on successful and economically effective rearing of juveniles with the density of 400 individuals per square meter of rearing area. With this density in the rearing troughs, the juveniles at the end of the $1^{\text {st }}$ growing season gain the size of 25-30 mm and cumulative survival 85\%. HAGER (1996), NYSTRÖM (1994), GYDEMO and WESTMAN (1993) recommend providing the juveniles with surplus shelters for more successful rearing. ACKEFORS et al. (1992) dealt with the nutrition of juveniles, recommending for their rearing the appropriate artificial feeds with $30-35 \%$ of proteins, $20-25 \%$ of carbohydrates and with low content of fat (below 10\%). KELLER (1987a) used zooplankton, grated carrot and artificial feeds for rearing the juveniles.

The goal of this study was to compare the effect of controlled and outdoor incubation of noble crayfish eggs on the hatching success (number of stage 2 juveniles per female), growth and survival of juveniles reared in the $1^{\text {st }}$ growing season.

\section{MATERIAL AND METHODS}

In autumn (October 1), 40 sexually mature adult noble crayfish were divided in two groups, each consisting of 15 females and 5 males. All crayfish were older than 4 years (92 $\pm 0.5 \mathrm{~mm}$ mean total body length) and they originated from Kramata natural reservoir in Šumava Protected Landscape Area. The entire experiment was carried out in the experimental facility and laboratory of the University of South Bohemia, Research Institute of Fish Culture and Hydrobiology, Department of Aquaculture and Hydrobiology at Vodňany.

\section{Controlled incubation of eggs}

The first group of crayfish was stocked into a fibreglass trough with $1.5 \mathrm{~m}^{2}$ area, placed in the laboratory. The mean total body length of stocked females was $90 \pm 0.3 \mathrm{~mm}$ and of stocked males was $96 \pm 0.5 \mathrm{~mm}$. Twenty plastic pipes were put into the trough as shelters, prior to stocking the crayfish. The trough was flown through ( $1 \mathrm{l} / \mathrm{min}$. flow-through) and it was connected to a recirculation system in the laboratory. Water temperature and dissolved oxygen content was monitored and controlled daily. When water temperature was above $10^{\circ} \mathrm{C}$, crayfish were fed with forage beet. Water quality was checked monthly $\left(\mathrm{pH},-\mathrm{NH}_{3},-\mathrm{NO}_{2}^{-}\right.$and $\left.-\mathrm{NO}_{3}{ }^{-}\right)$. Water quality of all samples referred to the requirements of noble crayfish according to APPELBERG (1984), SVOBODOVÁ (1987), and POLICAR et al. (2003). 
Females and males mated under these controlled conditions during October. Mating and oviposition in females was observed individually. Males were captured and removed from the trough after mating. Thirteen females spawned within several days after mating, and their eggs were fertilized and fixed to pleopods on abdomen. Two females did not spawn and they were removed from the trough.

Ovigerous females were kept together (density of 8.66 females per $1 \mathrm{~m}^{2}$ ) in the trough during controlled egg incubation. Females with embryos at the egg phase XIII (eye pigment) were individually placed into Rückel-Vacek incubators described in POKORNÝ et al. (1998). Ovigerous females were subjected to temperature-controlled egg incubation in the fibreglass trough according to CUKERZIS et al. (1978) and the $d_{3}$ variant of CELADA et al. (1988). The entire duration of controlled egg incubation was divided into three periods according to CUKERZIS et al. (1978):

1. The first period - duration of this period varied for individual females, as they were releasing eggs consequently (min. 25 days; max. 35 days; mean duration 30 days). Mean water temperature was $6.9 \pm 1{ }^{\circ} \mathrm{C}$. Eggs of all females gained the phase IV (beginning of gastrulation) in October 31. The embryonic development was observed and assessed according to CELADA et al. (1991) and ZEHNDER (1934).

2. The second period (decreasing the water temperature) - this period begun on December 1 , decreasing the water temperature to $3.5^{\circ} \mathrm{C}$. Mean water temperature in this period was $2.6 \pm 0.6^{\circ} \mathrm{C}$. Decreased water temperature at this period decelerated the embryonic development. The second period was terminated in December 15, after 15 days.

3. The third period (increasing the water temperature) - This period started in December 16, by consequent increasing the water temperature without expressive temperature jumps. Mean water temperature in this period was $12.5 \pm 3^{\circ} \mathrm{C}$. Termination of embryonic development was registered in April 3 when all embryos gained the developmental stage I. All females in the trough were separated individually to this date. Moulting and isolation of so-called advanced juvenile crayfish took place in April 10.

The first and the second periods lasted for 45 days. Mean water temperature in these periods was $5.5 \pm 2^{\circ} \mathrm{C}$. Water temperature in the third period was increased what led to the hatching of juveniles. This approach to controlled incubation according to CUKERZIS et al. (1978) contemporarily fulfilled the conditions of controlled egg incubation presented by CELADA et al., (1988) in the $d_{3}$ variant. The illumination was constant during egg incubation (8 L: $16 \mathrm{D})$.

\section{Out-door incubation of eggs}

The second group of crayfish was stocked into an earthen storage pond $5 \mathrm{~m}^{2}$ in area. The mean total body length of stocked females was $91 \pm 0.4 \mathrm{~mm}$ while that of males was $97 \pm 0.5 \mathrm{~mm}$. In the storage pond the shore area had a sandy and a clayey bottom with some larger stones. The depth was $1.5 \mathrm{~m}$ deep and the supply of water was $5 \mathrm{l} / \mathrm{min}$. Twenty shelters, about $200 \mathrm{~mm}$ in size, were created from stone in the storage pond. At the time of out-door egg incubation there were no macrophytes but plenty of macro-invertebrates (Chironomus sp., Paraleptophlebia sp., Sympetrum sp., Caenis sp., Dixa sp.) were found. The crayfish, 15 females and 5 males, were kept together ( 4 crayfish per $\left.1 \mathrm{~m}^{2}\right)$ during outdoor incubation. Water temperature was not controlled and the incubation of eggs took part under out-door conditions. Water temperature was checked daily and water quality was checked monthly $\left(\mathrm{pH},-\mathrm{NH}_{3},-\mathrm{NO}_{2}{ }^{-}\right.$and $\left.-\mathrm{NO}_{3}{ }^{-}\right)$. Water quality of all samples referred to the requirements of noble crayfish according to APPELBERG (1984), SVOBODOVÁ (1987) and POLICAR et al. (2003). Crayfish were not fed supplementally. Neither mating, nor egg ovulation were observed in detail, as the females were not disturbed. The storage 
pond was harvested at the end of June (26/6) and 15 females with eggs were transferred to the crayfish rearing station. Females with embryos at the egg phase XIII (eye pigment) were individually placed into Rückel-Vacek incubators. Termination of the embryonic development was registered in July 1 and the embryos were in the stage 1 hatchlings. Moulting and isolation of juvenile crayfish took place in July 7 .

\section{Comparison of hatching success from the controlled- and out-door egg incubation}

At the end of controlled- and out-door egg incubation females with embryos at the egg phase XIII (eye pigment) were individually placed into Rückel-Vacek incubators. After the first moulting and isolation of juvenile crayfish, all the juveniles in the stage 2 juveniles from every separated female of each group were individually counted. The hatching success (number of stage 2 juveniles per female) was registered for both groups. The difference in hatching success between both groups of females was statistically tested using one-way ANOVA ( $\alpha<0.05$, Microsoft Excel XP).

\section{Growth and survival of the advanced- and normally hatched juveniles reared in the $1^{\text {st }}$ growing season}

After isolation, the advanced crayfish juveniles and the normally hatched crayfish juveniles were separately reared in two rearing troughs, $1.5 \mathrm{~m}^{2}$ in area each, under controlled laboratory conditions for the course of the $1^{\text {st }}$ growing season. Twenty perforated bricks creating 700 shelters for the juveniles were put in each trough before the juveniles were stocked. Initial density of both groups of juveniles was 400 individuals in the stage 2 per 1 square meter of rearing area. Juvenile crayfish were daily fed with live graded zooplankton. Food remnants were removed from the trough before every next feeding. Water temperature and dissolved oxygen content in water were checked daily. The water temperature $\left(20.5 \pm 0.2^{\circ} \mathrm{C}\right)$ and illumination (12 L: $\left.12 \mathrm{D}\right)$ were constant during rearing of juveniles in the $1^{\text {st }}$ growing season. Water quality $\left(\mathrm{pH},-\mathrm{NH}_{3},-\mathrm{NO}_{2}^{-} \mathrm{a}-\mathrm{NO}_{3}{ }^{-}\right)$ was monitored weekly. Water quality of all samples referred to the requirements of noble crayfish according to APPELBERG (1984), SVOBODOVÁ (1987), POLICAR et al. (2003) and it was identical in both troughs.

Growth and survival were checked in each group of juvenile crayfish at 30-day intervals by control harvest of the trough. Number of surviving crayfish in the given trough was registered. Data on survival were used to compute the value of cumulative survival (\%) of juvenile crayfish in the given period. Representative samples of 33 specimens were individually measured to check total body length $(\mathrm{mm})$ and weight $(\mathrm{g})$ of juvenile crayfish. These biometric data were used to test growth of both groups of juvenile crayfish using one-way ANOVA $(\alpha<0.05$, Microsoft Excel XP). Growth of juveniles was tested within a given period and at a given age.

\section{RESULTS}

\section{Controlled- and out-door incubation of eggs}

The mean controlled incubation of eggs of the 13 females lasted for $154 \pm 5$ days. This consisted of the first period, $30 \pm 5$ days, the second period, $15 \pm 0$ days, and the third period, $109 \pm 0$ days. In total, the mean incubation of noble crayfish eggs under controlled conditions lasted for $1554 \pm 47$ CTU (Celsius Temperature Units = degrees Celsius $X$ days). Due to controlled egg incubation, hatching of so-called advanced juvenile crayfish was 88 days earlier than that of juveniles incubated under out-door conditions.

The running of temperature was not observed in detail during out-door egg incubation, in order not to disturb the females. The out-door conditions led to later hatching of normal hatched juveniles. 


\section{Comparison of hatching success from the controlled- and out-door egg incubation}

Hatching was less successful after controlled egg incubation: $47 \pm 25.0$ individuals stage 2 juveniles per female. The advanced juvenile crayfish were obtained from only 11 females, as two females lost all eggs during controlled egg incubation.

Hatching of eggs on females which have been kept under out-door conditions for egg incubation was significantly more successful (ANOVA, $F_{\text {krit }}=4,301 ; p=0,000421$; $90.1 \pm 46.9$ individuals of the stage 2 juveniles per female). During out-door incubation eggs, no female lost all eggs.

Growth and survival of the advanced- and normally hatched juveniles reared in the $1^{\text {st }}$ growing season

In all cases, rearing of both the advanced- and normal juveniles during the $1^{\text {st }}$ growing season resulted in significantly higher mean growth of the advanced juveniles compared to those from out-door egg incubation (Fig. 1). The advanced juveniles reached a mean body length of $26.0 \pm 3.06 \mathrm{~mm}$ and a mean weight of $0.585 \pm 0.197 \mathrm{~g}$ at the end of October (end of rearing the juveniles), compared to normally hatched juveniles which reached mean body length $21.3 \pm 2.25 \mathrm{~mm}$ and weight $0.305 \pm 0.101 \mathrm{~g}$ in this period.

When the growth gained by both groups of juveniles at a given age was compared, it was found that at an age of 30 days the advanced juveniles (mean body length $13.9 \pm 1.00 \mathrm{~mm}$ and mean weight $0.059 \pm 0.011 \mathrm{~g}$ ) had a significantly higher growth

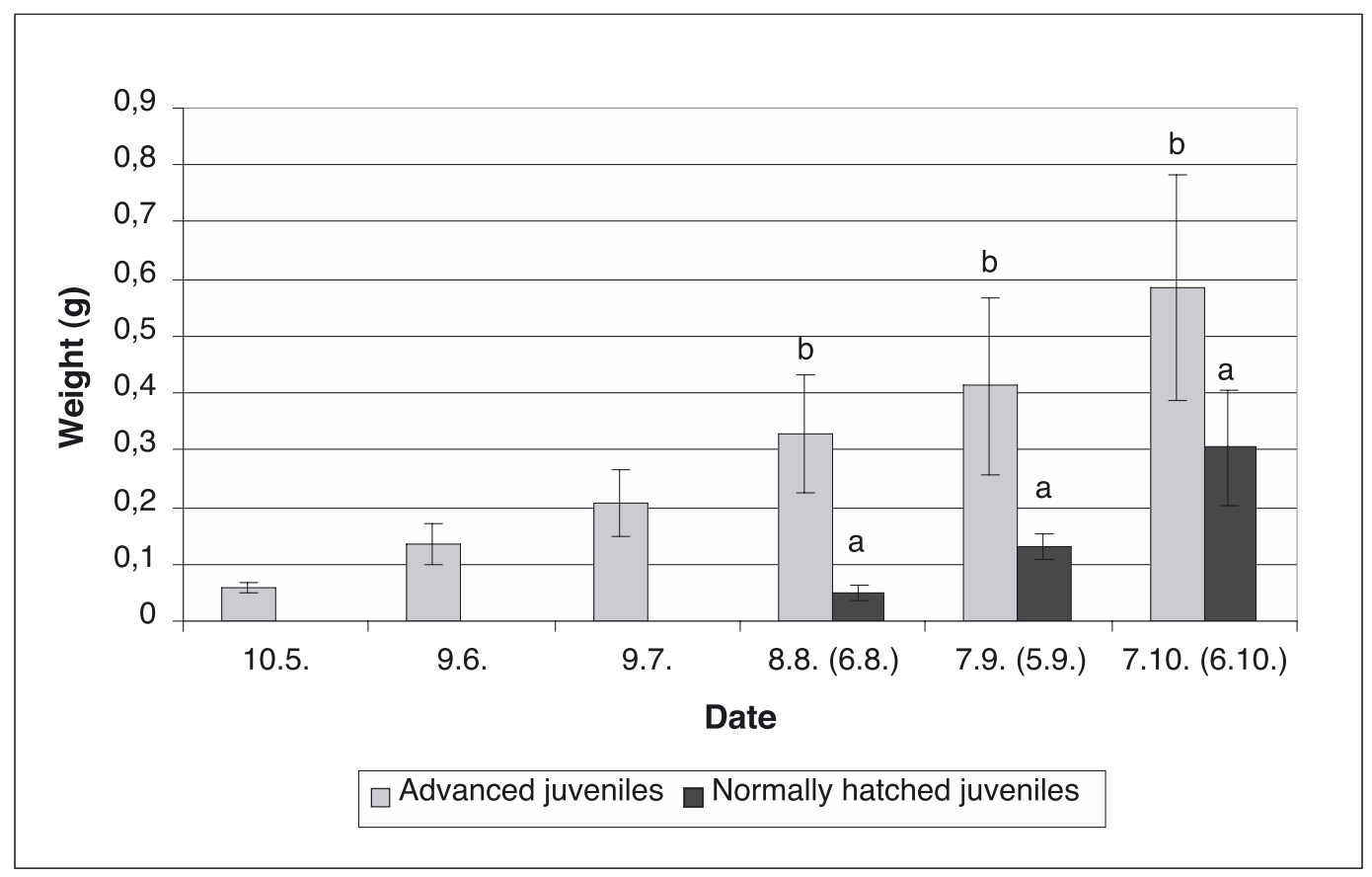

\section{Figure 1}

Weight growth of advanced- and normally hatched crayfish juveniles reared in the $1^{\text {st }}$ growing season.

\section{Figure 1}

Croissance en masse des juvéniles précoces et normalement éclos pendant la 1 ère période de croissance. 


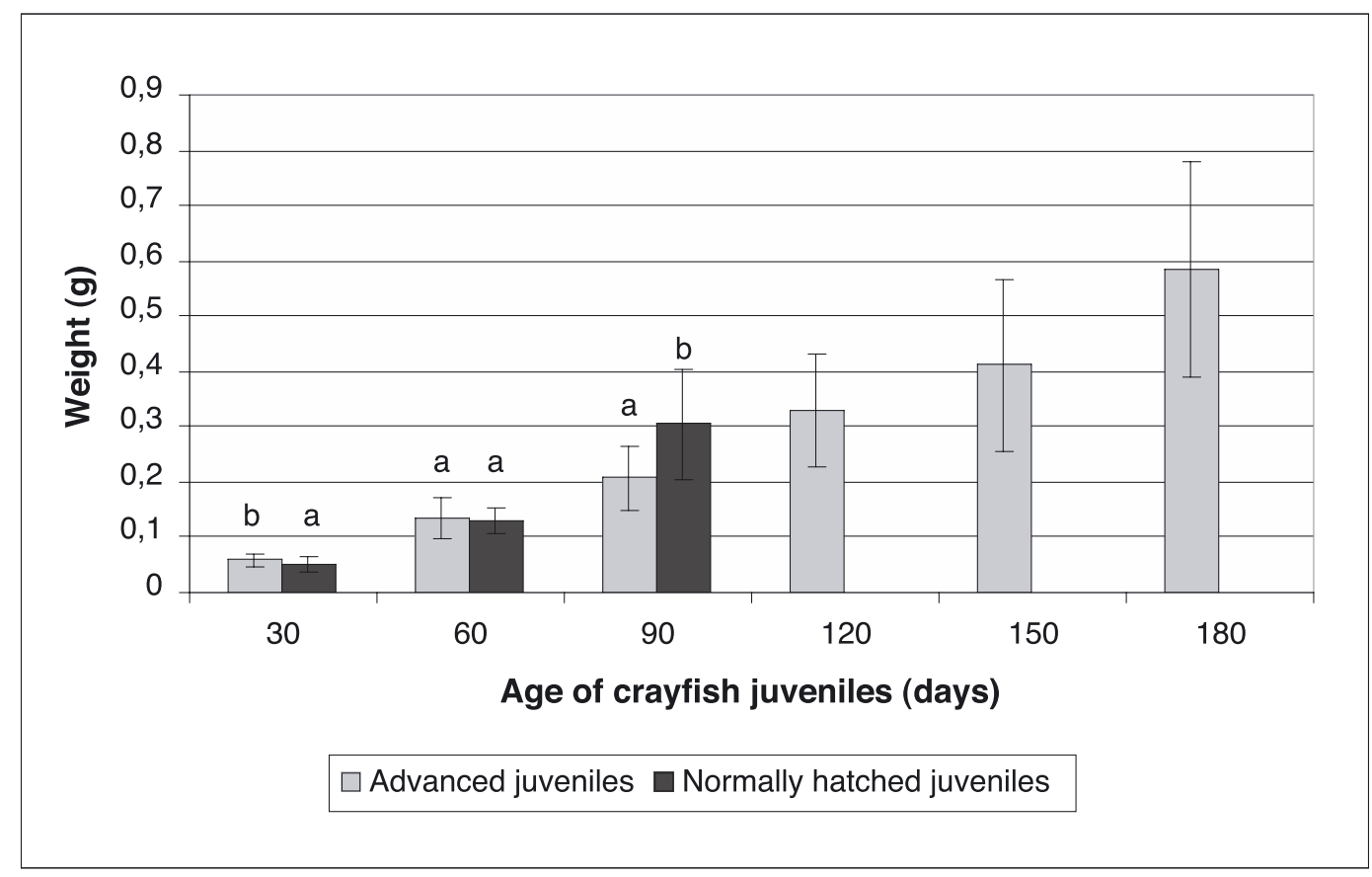

Figure 2

Weight growth of advanced- and normally hatched crayfish juveniles at the given age.

Figure 2

Croissance en masse des juvéniles précoces et normalement éclos à un âge donné.

(ANOVA, $F_{\text {krit }}=3,9909 ; p=0,0092$ ) than the normally hatched juveniles (mean body length $13.1 \pm 0.87 \mathrm{~mm}$ and mean weight $0.051 \pm 0.013 \mathrm{~g}$ ). No significant difference was found between both groups of juveniles at the age of 60 days. The advanced juveniles reached a mean body length of $16.7 \pm 1.52 \mathrm{~mm}$ and a mean weight of $0.136 \pm 0.037 \mathrm{~g}$ compared to normally hatched juveniles of the same age (mean body length $16.4 \pm 1.23 \mathrm{~mm}$ and mean weight $0.131 \pm 0.023 \mathrm{~g}$ ). At the age of 90 days, the advanced juveniles (mean body length $20.2 \pm 1.83 \mathrm{~mm}$ and mean weight $0.207 \pm 0.058 \mathrm{~g}$ ) were found to have significantly slower growth (ANOVA, Fkrit $=3,9909 ; p=0,00001$ ) than the normally hatched juveniles of the same age (mean body length $21.3 \pm 2.25 \mathrm{~mm}$ and mean weight $0.305 \pm 0.101 \mathrm{~g}$ (Fig. 2).

Comparing the survival rate between both groups of juvenile crayfish, higher mortality rate was found in all rearing periods for the advanced juveniles than for the normally hatched ones. At the age of 90 days, the advanced juveniles showed $21 \%$ less survival rate than the normally hatched ones. At the end of rearing, survival rates of the advanced juveniles (age of 180 days) and of the normally hatched ones (age of 90 days) were $17.2 \%$ and $47.2 \%$, respectively (Fig. 3 ).

\section{DISCUSSION}

\section{Controlled- and out-door incubation of eggs}

The controlled- incubation of eggs lasted for $154 \pm 5$ days as a mean. The hatching occurred in beginning of April. According to CUKERZIS et al. (1978), CUKERZIS (1989), 


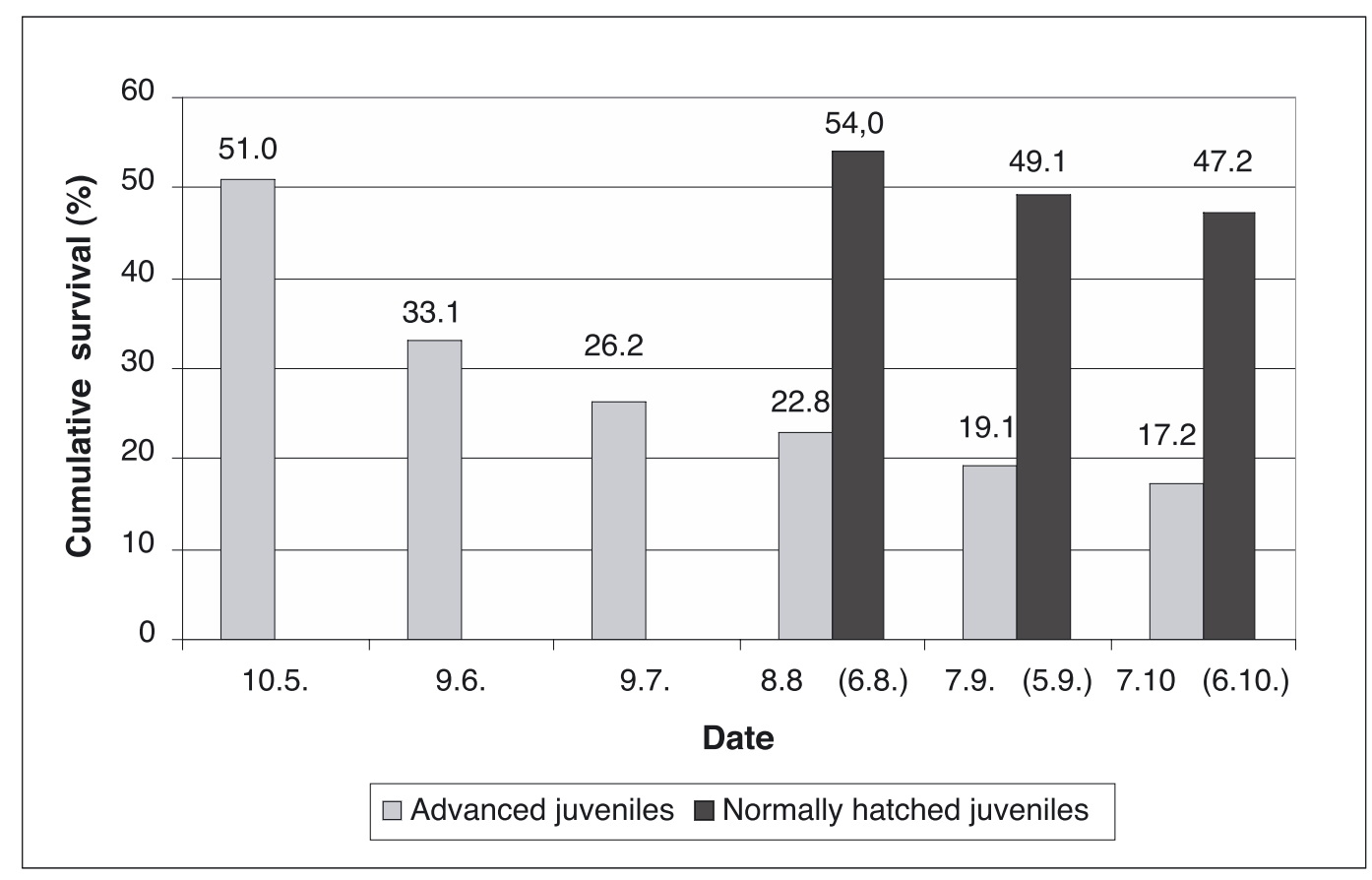

Figure 3

Cumulative survival of advanced- and normally hatched crayfish juveniles reared in the $1^{\text {st }}$ growing season.

\section{Figure 3}

Survie cumulée des juvéniles précoces et normalement éclos pendant la $1^{\text {re }}$ période de croissance.

and TAUGBØL and SKURDAL (1990a), the incubation of noble crayfish eggs under natural conditions of Central Europe lasts from October till June, i.e. about 240 days. It can be stated that using controlled water temperature, the duration of egg incubation was shortened. The date of hatching of the advanced juveniles was later than dates presented by CUKERZIS et al. (1978), CUKERZIS (1989), STREMPEL (1973), and WESTIN and GYDEMO (1986) for hatching of advanced juveniles in the noble crayfish and than those presented by CELADA et al. (2001) for hatching of advanced juveniles in the white-clawed crayfish.

After controlled incubation, the advanced juveniles became free 88 days earlier than those from out-door egg incubation (the date of hatching of normally hatched juveniles was July 1). These 88 days prolonged the rearing period of advanced juvenile crayfish. The shortening of the out-door incubation of eggs has been described by different authors, and the growth season can be extented (ACKEFORS, 1993; CUKERZIS et al., 1978; CUKERZIS 1988 and 1989; CELADA et al., 1988; CARRAL et al., 1992; KÖKSAL, 1988; MACKEVIĖIENË et al., 1997; MASON, 1977; PÉREZ et al., 1998 and 1999; REYNOLDS et al., 1992, and RHODES, 1981). CUKERZIS (1989) reports that the duration of rearing of the advanced crayfish juveniles can be prolonged by controlled egg incubation for 130140 days maximum. The period to hatching in the noble crayfish may be shortened from the natural 9 months to 4 months (WESTIN and GYDEMO, 1986) or to 5 months (HESSEN et al., 1987) by holding females at the controlling temperature of water.

The sum of CTU for the controlled egg incubation leading to hatching of advanced juveniles was found to be a mean of $1554 \pm 47$ CTU. This refers to data presented by 
CUKERZIS (1973), KELLER (1987b) and HOFMANN (1980), but this data is estimated to be the requirement for hatching in nature. On the contrary, the sum of CTU found in this study differed from data of TAUGBØL and SKURDAL (1990a), PURSIAINEN et al. (1983). Large differences were recorded in the required CTU for hatching of the noble crayfish (1,300 to $1900 \mathrm{CTU})$. The noble crayfish obviously have a great flexibility in required CTU, where higher temperatures have the effect of lowering the required amount of heat needed for embryonic development (HESSEN et al., 1987). The temperature of out-door egg incubation was always lower than temperature of controlled egg incubation. This means, that the sum of CTU for hatching normally hatched juveniles was probably higher that the sum of CTU for hatching advanced hatched juveniles

\section{Comparison of hatching success from the controlled- and out-door egg incubation}

Females, which have been placed under controlled conditions for egg incubation, were found to have significantly less successful hatching (number of stage 2 juveniles per female) than those that have been kept under out-door conditions. The registered hatching success of controlled egg incubation referred to the hatching success from controlled egg incubation of CUKERZIS et al. (1978). The lower hatching success in controlled egg incubation was caused by higher egg losses.

Date of mating and spawning was checked in females during controlled egg incubation. On the other side, during out-door egg incubation, date of mating and spawning was not checked and females were not disturbed. This fact could lead to higher egg losses during controlled egg incubation.

Post-spawning egg losses in the noble crayfish have been observed in nature conditions (TAUGBØL and SKURDAL, 1989, 1990a), in ponds (PURSIAINEN et al., 1983) and in controlled conditions (CUKERZIS, 1989; TAUGBØL and SKURDAL, 1990b). CUKERZIS (1989) described losses of eggs during controlled incubation caused by the stress of females which were kept together in tanks. TAUGBØL and SKURDAL (1990b) examined the effect of females density on eggs survival during winter incubation. At higher density of egg-bearing females lower eggs survival was noted during winter incubation of eggs. Egg-bearing females held in individual compartments had the lowest eggs survival (TAUGBØL and SKURDAL, 1990b). These authors used higher densities of 44 and 33 eggbearing females per $1 \mathrm{~m}^{2}$ during winter incubation than was used in our experiments as guaranteed lower egg losses. CARRAL et al. (1992) and CELADA et al. (1988) reported losses of eggs for the signal crayfish due to controlled egg incubation. They found the losses ranging in 17.8-90.0\%, according to various methods of controlled incubation.

Conditions during controlled incubation may have caused lower egg losses. However higher egg losses were established during controlled egg incubation than during out-door egg incubation. Loss of all eggs was observed in two females, which were kept in the trough during controlled egg incubation. SAVOLAINEN et al. (1997), TAUGBØL and SKURDAL (1990b) confirmed the loss of all eggs in several females that were kept in the tanks during egg incubation.

Our results agree with opinion of FEDOTOV (1993) that more successful hatching in the noble crayfish is performed in conditions that are more similar to natural conditions. In nature, females with total egg loss were not recorded. In nature, conditions are more favourable for higher egg survival (TAUGBØL and SKURDAL, 1990b).

\section{Growth and survival of the advanced and normally hatched juveniles reared in the $1^{\text {st }}$ growing season}

In the course of rearing the advanced- and normal juveniles, the advanced juveniles always showed significantly higher mean size (body length and weight) in the given 
period compared to those from out-door egg incubation. This was due to the fact that the advanced juveniles were 88 days older than the normally hatched ones. This confirmed the effect of shortened duration of egg incubation and prolongated duration of juvenile rearing in the $1^{\text {st }}$ growing season (ACKEFORS, 1993; CUKERZIS et al., 1978; MACKEVIÈIENË et al., 1997).

In the course of rearing, the advanced juvenile crayfish showed slower growth rate than the normally hatched ones. CUKERZIS (1989) found faster growth rate for the advanced juveniles than for the normally hatched juveniles and this author does not agree with our results on the rearing of advanced juveniles. SÁEZ-ROYUELA et al. (1995) did not observe significantly different growth rates between juveniles from artificial or maternal incubation in the signal crayfish (Pacifastacus leniusculus Dana). MASON (1977) noticed a smaller growth rate for the prematurely separated stage 2 juveniles signal crayfish than for the normal ones.

Apart from a slower growth rate, the advanced juveniles also had a lower survival rate compared to the normally hatched juveniles. CUKERZIS (1989) did not find a lower survival rate for the advanced juveniles in the noble crayfish. Significantly different survival rate of juveniles from artificial or maternal incubation in the signal crayfish was not described by SÁEZ-ROYUELA et al. (1995). MASON (1977) did not notice any negative influence of artificial incubation on the survival rates of prematurely separated stage 2 juveniles.

\section{CONCLUSION}

When incubating the eggs of noble crayfish, controlled water temperature shortened the incubation period which occurred at an earlier date of hatching which yielded the socalled advanced juveniles which had a prolonged period or rearing during the $1^{\text {st }}$ growing season.

The incubation of eggs of the noble crayfish under artificial conditions, which differ from natural conditions, affected hatching success negatively (number of stage 2 juveniles per female).

The advanced juvenile crayfish always showed significantly higher mean size in the given period than those normally hatched, because they were 88 days older. In the course of rearing, the advanced juvenile crayfish had lower survival and slower growth rates than the normally hatched ones.

Results gained in this study cannot be generalized because of small number of animals used.

\section{ACKNOWLEDGEMENTS}

This investigation was supported by the Ministry Education project No. MSM 126100001 and by the Ministry for Agriculture of the Czech Republic project NAZV QF 3028. Our thanks to Premek Hamr (Ontario, Canada) for the corrections of the English and Pascal Fontaine (Nancy, France) for the translation of the abstract in French.

\section{REFERENCES}

ACKEFORS H., 1993. Crayfish farming in Europe. In: From Discovery to Commerialization, (eds CARRILLO M., DAHLE L., MORALES J., SORGELOOS P., SVENNEVIG N., WYBAN J.), Ostende, Belgium, European Aquaculture Soc., 19, 99. 
ACKEFORS H., CASTELL J.D., BOSTON L.D., RATY P., SWENSSON M., 1992. Standard experimental diets for crustacean nutrition research. II. Growth and survival of juvenile crayfish Astacus astacus (Linné) fed diets containing various amounts of protein, carbohydrate and lipid. Aquaculture, 104, 341-356.

ACKEFORS H., LINDQVIST O.V., 1994. Cultivation of freshwater crayfish in Europe. In: Freshwater Crayfish Aquaculture in North America, Europe and Australia: Families Astacidae, Cambaridae, and Parastacidae (ed. J.V. HUNER), Haworth Press, Binghamton, NY, 157-216.

APPELBERG M., 1984. Early development of the crayfish Astacus astacus L. in acid water. Report Institute of the Freshwater Research, Drottningholm, 61, 48-59.

BLAKE M.A., HART P.J.B., 1993. Habitat preferences and survival of juvenile signal crayfish, Pacifastacus leniusculus - the influence of water depth, substratum, predatory fish and gravid female crayfish. Freshwater Crayfish, 9, 318-332.

CARRAL J.M., CELADA J.D., GONZÁLEZ J., GAUDIOSO V.R., F ERNÁNDEZ R., LÓPEZBAISSÓN C., 1992. artificial incubation of crayfish eggs Pacifastacus leniusculus D. from early stages of embryonic development. Aquaculture, 104, 261-269.

CELADA J.D., CARRAL J.M., GAUDIOSO V.R., CONSUELO T., FERNANDEZ R., 1988. Effects of thermic manipulation throughout egg development on the reprod uctive efficiency of the freshwater crayfish Pacifastacus leniusculus D. Aquaculture, 72, 341- 348.

CELADA J.D., CARRAL J.M., GONZÁLEZ, J., 1991. A study on the identification and chronology of the embryonic stages of freshwater crayfish Austropotamobius pallipes (Lereboullet, 1858). Crustaceana, 61, 225-232.

CELADA J.D., CARRAL J.M., SÁEZ-ROYUELA M., MUNOZ C., PÉREZ J.R., 2001. Effects of different thermal treatments on the maternal incubation efficiency of the astacid crayfish Austropotamobius pallipes (Lereboullet, 1858) under controlled conditions. Crustaceana, 74, 801- 808.

CUKERZIS J.M., 1973. Biologische Grundlagen der Metode der kunstlichen Aufzucht der Brut dese Astacus astacus L. Freshwater Crayfish, 1, 187-202, in German with English abstract.

CUKERZIS J.M., 1988. Astacus astacus in Europe. In: Freshwater Crayfish: Biology, Management and Exploitation, (eds HOLDICH, D.M. \& LOWERY, R.S.), Croom Helm, London, 309-340.

CURERZIS J.M., 1989. Rečnyje raky / Freshwater Crayfish. Monografija, Akademija nauk litovskoj SSR, Vilnius, 135 pp., in Russian only.

CUKERZIS J.M., SHESHTOKAS A.L., TERENTYEV A.L., 1978. Method for accelerated artificial breeding of crayfish juveniles. Freshwater Crayfish, 4, 452-458.

FEDOTOV V.P., 1993. Razveděnie rakov. Sankt Petěrburg, 106 pp., in Russian only.

GYDEMO R., WESTMAN L., 1993. Effects of starvation, constant light and partial dactylotomy on survival of noble crayfish, Astacus astacus (L.), under high density laboratory conditions. Freshwater Crayfish, 9, 79-86.

HAGER J., 1996. Edelkrebse / Freshwater Crayfish. Leopold Stocker Verlag, Graz - Stuttgart, 128 pp., in German only.

HESSEN D.O., TAUGBØL T., FJELD E., SKURDAL J., 1987. Egg development and lifecycle timing in the noble crayfish (Astacus astacus). Aquaculture, 64, 77-82. 
HOFMANN J., 1980. Die Flußkrebse / Freshwater Crayfish. 2. Auflage (von K.M. Strempel). Paul Parey, Hamburg, 110 pp., in German only.

KELLER M., 1987a. Finding a profitabe population density in rearing summerlings of European crayfish Astacus astacus L.. Freshwater crayfish, 7, 259-266.

KELLER M.M., 1987b. Research on the incubation period of Astacus astacus (L.) under natural conditions. Freshwater crayfish, 7, 363-367.

KOZÁK P., KOUŘIL J., HAMÁČKOVÁ J., 1998. Růst dvou skupin ráčat raka signálního (Pacifastacus leniusculus) získaných od samic chovaných v rybníce a oteplené vodě / Growth Mates of two groups of juvenilie signal crayfish Pacifastacus leniusculus originating from females reared in pond and warm water. Vodňany Bulletin VÚRH, 3, 99-102, in Czech with English abstract.

KÖKSAL G., 1988. Astacus leptodactylus in Europe. In: Freshwater Crayfish: Biology, Management and Exploitation, (eds HOLDICH, D.M. \& LOWERY, R.S.), Croom Helm, London, 365-400.

MACKEVIÈIENË G., MICKËNIENË L., BURBA A., KOREIVA È, 1997. Aquaculture of the noble crayfish, Astacus astacus L., in Lithuania. Freshwater Crayfish, 11, 599-607.

MASON J.C., 1977. Artificial incubation of crayfish eggs (Pacifastacus leniusculus Dana). Freshwater Crayfish, 3, 119-132.

NYSTRÖM P., 1994. Survival of juvenile signal crayfish Pacifastacus leniusculus in relation to light intensity and density. Nordic Journal of Freshwater Research, 69, 162166.

PÉREZ J.R., CARRAL J.M., CELADA J.D., SAEZ-ROYUELA M., ROMERO M.P., 1998. Effects of different thermal treatments throughout the embryonic development on the artificial incubation duration and implications for commercial production. Invertebrate Reproduction and Development, 34, 253-258.

PÉREZ J.R., CARRAL J.M., CELADA J.D., SAEZ- ROYUELA M., MUÑOZ C., ANTOLÍN, J.I., 1999. The possibilities for artificial incubation of white-clawed crayfish (Astropotamobius pallipes Lereboullet) eggs. Comparison between maternal and artificial incubation. Aquaculture, 170, 29-35.

POKORNÝ J., ADÁMEK Z., DVOŔÁK J., ŠRÁMEK V., 1998. Pstruhařství / The trout culture, Informatorium, Praha, 71- 83, in Czech only.

POLICAR T., MÁCHOVÁ J., KOZÁk P., 2003. Akutní toxicita volného amoniaku a dusitanů pro ročky raka říčního (Astacus astacus L.) / Accute toxicity of unionised ammonia and nitrite to yearlings of Noble crayfish (Astacus astacus L.). In: Toxicity and Biodegradability of Matters Important in Water Management (eds Dočkal, P., \& Máchová, J.), Proceedings of paper from conference, Soláň, 215-222, in Czech with English abstract [CD-ROM].

PURSIAINEN M., JÄRVENPÄÄ T., WESTMAN K., 1983. A comparative study on the production of crayfish Astacus astacus L. juveniles in natural food ponds and by feeding in plastic basins. Freshwater Crayfish, 5, 392-402.

REYNOLDS J.D., 2002. Growth and reproduction. In: Biology of Freshwater Crayfish, (eds D.M. Holdich), Blackwell Science Ltd., London, 152-191.

REYNOLDS J.D., CELADA J. D., CARRAL J.M., MATTHEWS M.A. 1992. Reproduction of astacid crayfish in captivity - current developments and implications for culture, with special reference to Ireland and Spain. Inverterbrate Reproduction and Development, 22, 253-266. 
RHODES C.P., 1981. Artificial incubation of the crayfish Austropotamobius pallipes Lereboullet. Aquaculture, 25, 129-140.

SÁEZ-ROYUELA M., CARRAL J.M., CELADA J.D., MUNOZ C., 1995. Effects of management on survival and growth of stage 2 juvenile freshwater signal crayfish (Pacifastacus leniusculus Dana) under laboratory conditions. Aquaculture, 133, 123-133.

SAVOLAINEN R., WESTMAN K., PURSIAINEN M., 1997. Fecundity of Finnish noble crayfish, Astacus astacus L., and signal crayfish, Pacifastacus leniusculus, in various natural habitats and in culture. Freshwater Crayfish, 11, 319-338.

SKURDAL J., WESTMAN K., BERGAN P.I., 1989. Crayfish culture in Europe. Report from the Workshop on Crayfish Culture, November 1987, Trondheim, Norway, 16-19.

STREMPEL K.M., 1973. Edelkrebserbrutungin Zuger-Glasernund anfutterung der krebsbrut. Freshwater Crayfish, 1, 234-238, in German with English abstract.

SVOBODOVÁ Z., 1987. Toxikologie vodních živočichů / The toxicology of aquatic animals, Praha, 189-193, in Czech only.

TAUGBØL T., SKURDAL J., 1989. Effect of indoor, culture conditions on maturation and fecundity of wild-caught female noble crayfish, Astacus astacus. Aquaculture, 81, $1-12$.

TAUGBØL T., SKURDAL J., 1990a. Reproduction, moulting and mortality of female noble crayfish, Astacus astacus (L.,1858), from five Norwegian populations subjected to indoor culture conditions (Decapoda, Astacoidea). Crustaceana, 58, 113-23.

TAUGBØL T., SKURDAL J., 1990b. Effect of density on brood size in noble crayfish, Astacus astacus L., subjected to indoor rearing conditions. Aquaculture and Fisheries Management, 1990, 21, 17-23.

TULONEN J., ERKAMO E., KIRJAVAINEN J., 1995. Growth rate, surfoval and reproduction of noble crayfish Astacus astacus L. and signal crayfish Pacifastacus leniusculus under similar rearing conditions. Freshwater Crayfish, 10, 623-629.

WESTIN L., GYDEMO R., 1986. Influence of light and temperature on reproduction and moulting frequency in the crayfish, Astacus astacus. Aquaculture, 52, 43-50.

ZEHNDER H., 1934. Uber die Embryonalentwicklung des Flusskrebses. Acta Zoologica, 15, 261-408. 
